\title{
Direct Mercury Analyzer (DMA) determination of mercury distribution in the sediments of lake Nokoué in Benin Republic-West Africa
}

\author{
N. B. Nadia AZON ${ }^{1,3^{*}}$, Peace HOUNKPE ${ }^{1}$, Julien G. ADOUNKPE ${ }^{1,2}$, \\ Hermione W. DEGILA ${ }^{1,3}$ and Martin P. AINA ${ }^{1,3}$ \\ ${ }^{1}$ Laboratory of sciences and Technics of water of National Institute of water, University of Abomey-Calavi, \\ Benin. \\ ${ }^{2}$ Laboratory of Applied Ecology of Agronomic Science Faculty University of Abomey-Calavi, Benin. \\ ${ }^{3}$ Laboratory of Environmental study and monitoring, Cotonou, Benin. \\ *Corresponding author; E-mail: noubruna87@gmail.com; Tel: 0022996496070
}

\begin{abstract}
Received: 25-09-2020
Accepted: 18-02-2021

Published: 28-02-2021

ABSTRACT

Mercury pollution of water bodies constitutes a hazard to both the aquatic life and the populations consuming fishery products. To anticipate the probable eco-toxicological risks that may arise from the largest lake in southern Benin, the present work aims at assessing the mercury status of the sediments of Lake Nokoué, while identifying the areas exposed to anthropogenic mercury contamination. 45 sites were sampled according to a grid plan covering the entire ecosystem of the lake. Employing a Van Veen grab, surface sediments are collected at a depth from 0 to $5 \mathrm{~cm}$ in three catches at each site. The composite samples formed at equal mass on the three portions were frozen, lyophilized at $-40{ }^{\circ} \mathrm{C}$, crushed, sieved and homogenized. Fraction less than 63 $\mu \mathrm{m}$ was collected for the mercury content determination by Direct Mercury Analyzer (DMA) operating by atomic absorption according to the US EPA 7473 method. The mercury concentration varies from $1.56 \mu \mathrm{g} / \mathrm{kg}$ to 164.88 $\mu \mathrm{g} / \mathrm{kg}$ with an average value of $35.18 \mu \mathrm{g}$ per $\mathrm{kg}$ of sediment. The south-eastern zone of the lake is more concentrated in mercury with a summation of the mercury content of $530.3 \mu \mathrm{g} / \mathrm{kg}$ of sediment. However, the lake has moderate contamination overall $(1 \leq \mathrm{FC} \leq 3)$.
\end{abstract}

(c) 2021 International Formulae Group. All rights reserved.

Keywords: Pollution, contamination, mercury, sediment, Lake Nokoué.

\section{INTRODUCTION}

In an aquatic environment, the sediment is positioned as a preferred segment when it comes to the study of pollutants. Sediment has in fact been shown by several authors to be the place of accumulation and persistency of many hazardous metals (Diop et al., 2014; Saher et al., 2016; Nahli et al., 2016; Sousou et al., 2019). Among the sediment micropollutants, mercury is a metal that is highly toxic to both aquatic fauna and flora and to human health (Dominique, 2014). When stored in sediment, mercury can be remobilized in water and entered the food chain through the process of biomagnification (Degila et al., 2019). In Benin Republic, several studies on heavy metals have been carried out on the largest lake in the south of the country, the Lake Nokoué (Dovonou et al., 2011; Chouti et al., 2011; Hounkpatin et al., 2011; Youssao et al., 2011; Alassane et al., 
2018; Adechina et al., 2019), but very little is really directed towards the mercury pollution of the lake sediments. Indeed, Chouti (2011) and Yehouenou (2013) have, demonstrated respectively a mercury contamination of the sediments of the village of Boudèdomey at the vicinity of the Porto-Novo lagoon and in the village of Ganvié at the level of the lake Nokoué. However, the study of the distribution of mercury over the entire sedimentary environment has never been carried out.

In addition, Lake Nokoué, one of the most productive and most exploited water complex in West Africa (Yehouenou, 2013) is increasingly under the threat of metal pollution. In fact, the waters and sediments of the lake and of the Cotonou channel are contaminated by cadmium, copper, zinc, iron, mercury and arsenic (Agonkpahoun, 2006; Lawani, 2007; Darboux, 2008). Studies of fish caught at the lakeside of Ganvié show contamination by cadmium and lead, a potential health risk for the population that consumes the fish (Yehouenou, 2013). The evaluation of the metallic pollution of the lake, carried out over a period of three years by Yehouenou (2013) reveals that the ecosystem is polluted by lead, cadmium, zinc and mercury. According to the same author, the uncontrolled dumping of waste is the cause of the high lead concentrations measured in sediments, fish, shrimp and oysters at Ganvié and SoTchnahoué. In addition, the highest mercury concentrations in water (> $1 \mathrm{mg} / \mathrm{L})$ are observed at Dantokpa and Ahouansori. This could mean that the measured mercury is related to point pollution or drained from a diffuse source. Thus, a more in-depth investigation of mercury pollution of lake Nokoué would be an asset, especially in a context where Benin is a signatory party of the Minamata convention on mercury since 2017.

The present work, part of a spatial assessment of the mercury contamination of sediments in Lake Nokoué, is interested in establishing the correlation between mercury and some environmental parameters and in evaluating the ecological risk of the sediments through the calculation of quality indices.

\section{MATERIALS AND METHODES}

Area of study

Nokoue is the largest lake in southern Benin Republic, with an average length of 20 $\mathrm{km}$ (east - west) and a width of $11 \mathrm{~km}$ (north south). It covers a surface area of around 150 $\mathrm{km}^{2}$ with a low water level and lies between parallels $6^{\circ} 20$ ' and $6^{\circ} 35^{\prime} \mathrm{N}$ latitude and meridians $2^{\circ} 20$ ' and $2^{\circ} 33^{\prime}$ E longitude. Lake Nokoue connects, to the north, with the Sô delta, to the east with the Porto-Novo lagoon and the Ouémé river, to the south with the channels of Totchè canal and of Cotonou.

Lake Nokoué banks are occupied by the major cities such as Cotonou in the south, Abomey-Calavi in the west, and Sèmè-Kpodji in the east. It is home to some lakeside villages, the most coveted for tourism is Ganvié (Figure $1)$.

\section{Sampling and conditioning}

Sediment samples are collected in April 2018, following a grid plan of the entire lake (Figure 2). A total of 45 georeferenced sites, equidistant of $2.25 \mathrm{~km}$ are sampled. At each site, three sediment sample at points, separated by one to two meters apart, are collected; each to a depth from 0 to $5 \mathrm{~cm}$ using a Van Veen manual bucket. Each sample is collected in a polyethylene bag, labeled and then stored at 4 ${ }^{\circ} \mathrm{C}$ prior to getting to the laboratory.

\section{Pretreatment and analysis}

In the laboratory, the samples are treated in accordance with the NF ISO 11464 standard. They are first lyophilized at $-40{ }^{\circ} \mathrm{C}$, then crushed, sieved and homogenized. The composite samples are prepared according to a mixture of equal mass of the three samples per site. These samples are then sieved on a sieve with a porosity of $2 \mathrm{~mm}$ at first. This fraction was used for the determination of water $\mathrm{pH}, \mathrm{eH}$ and organic matter. Secondly, the samples are sieved at a porosity of $63 \mu \mathrm{m}$. The fine fraction $(<63 \mu \mathrm{m})$ is recovered for the determination of mercury.

The mercury determination is carried out by cold vapor Atomic Absorption Spectrometry, with the Direct Mercury Analyzer (DMA-80) following the US EPA 
7473 method. The total mercury contained in a mass of $100 \mathrm{mg}$ of sample is subjected to a flow of oxygen, for incineration and amalgamation with gold.

\section{Statistical analysis}

A descriptive analysis is done on all the data. On lake Nokoué, the distribution of the studied parameters is highlighted through the boxplots. The correlation between the various parameters studied is evaluated using the Pearson test with a statistical significance set at $\mathrm{p}<0.04$. Analysis of variance is done to assess the effect of sampling areas and other parameters on mercury concentration.

\section{Ecological risk assessment}

The assessment of the quality of the sediments studied is made by calculating the geo-accumulation index (Igeo) (Nahli et al., 2016; Müller, 1981), the contamination factor (FC) (Sahli, 2012; Rubio et al., 2000) and by comparing the mercury contents by sites with sediment quality guide values such as TEC

$$
\text { Igeo }=\log 2\left(\frac{C m}{1,5 x C f g}\right) \quad F C=\left(\frac{C m}{C f g}\right)
$$

(Threshold Effect Concentration) and PEC (Probable Effect Concentration) according to MacDonald (2000).

* Cm: concentration of the metal measured

* Cfg: concentration of the geological background of the metal

* The value of the background noise here used for mercury is $56 \mu \mathrm{g} / \mathrm{kg}$ (Soussou et al., 2019; Wedepohl, 2015).

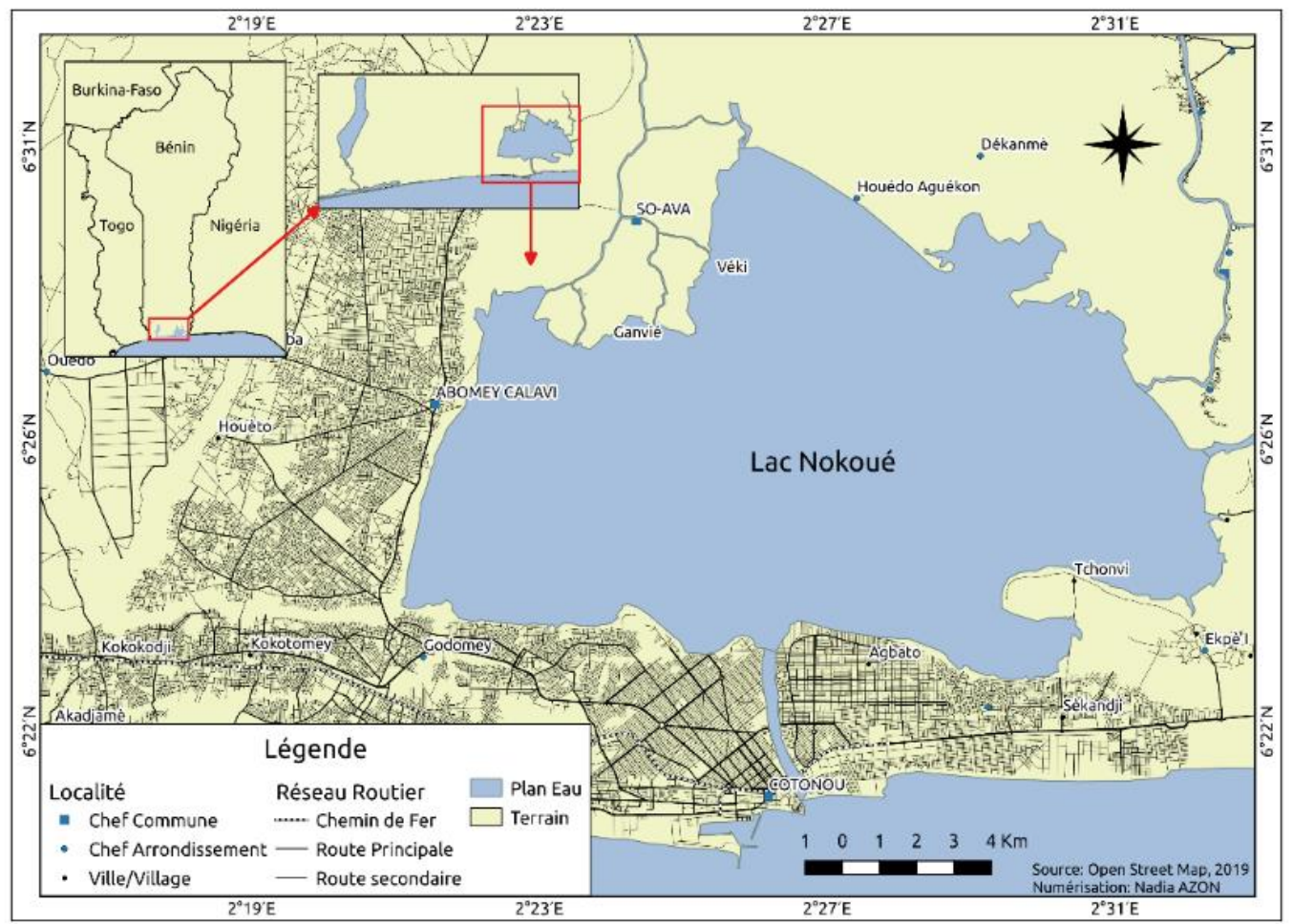

Figure 1: Geographical location of Lake Nokoué. 


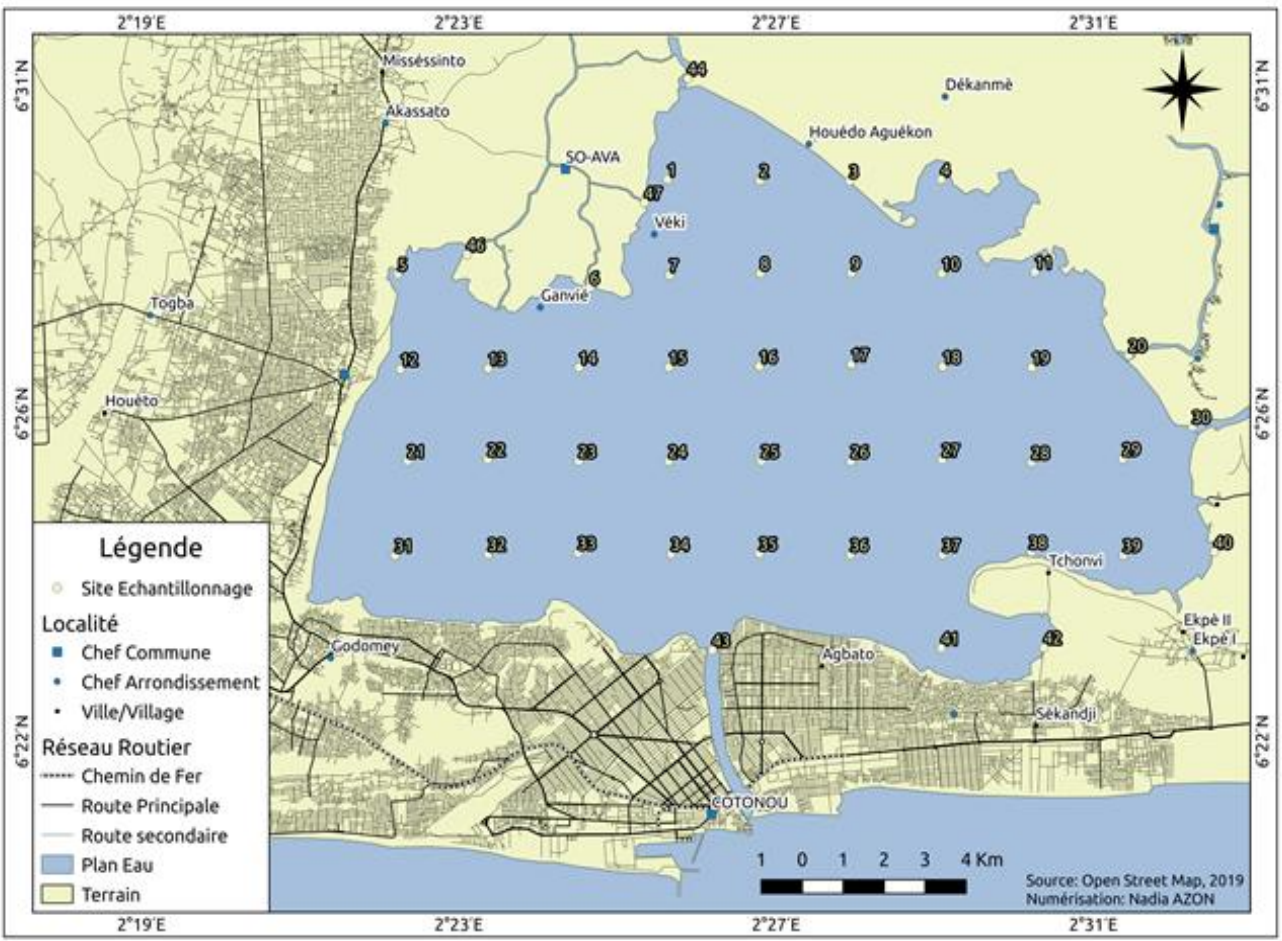

Figure 2: Map of Lake Nokoué showing georeferenced sampling points.

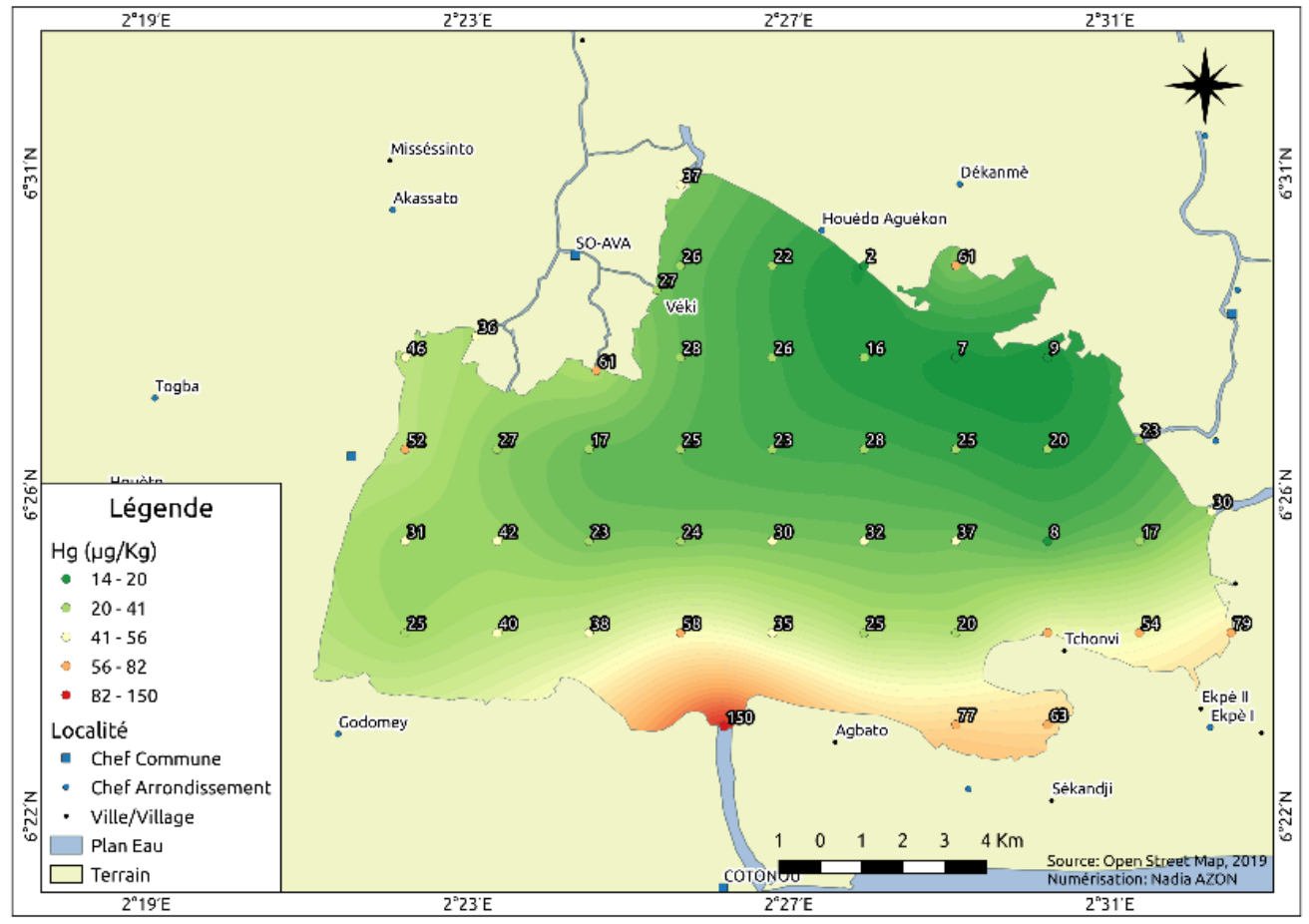

Figure 3: Distribution of the mercury concentration on Lake Nokoué. 


\section{RESULTS}

\section{Mercury distribution}

Sediments at tributaries show that the sediment content of mercury from the Sô-Awa river to the lake varies from $27 \mu \mathrm{g} / \mathrm{kg}$ to $61 \mu \mathrm{g} / \mathrm{kg}$. The minimum content of this tributary remains however lower than that observed at the entrance of the tributary at the Ouémé river. The mercury concentration becomes much more noticeable in the eastern and western parts of the lake going south with the highest concentrations downstream. Indeed, the southern peripheral area of the lake is sheltered by household waste dumps (Hounkpe et al., 2017). This corroborates with the concentrations in the lake water at Dantokpa and Ahouansori related to the waste dumped in the lake (Yehouenou, 2013).

\section{Physical-Chemical parameter of sediments}

Table 1 presents a general description of the parameters involved in this study. It appears that the average $\mathrm{pH}$ value of the medium is 6.63 with a maximum value of 8.12. The $\mathrm{pH}$ values below 5 are obtained at the entry points of the Sô river, the Ouémé river and the Djonou tributary. The proportions of organic matter evaluated by loss on ignition at $550{ }^{\circ} \mathrm{C}$ reveal that the studied sediments are highly loaded with organic matter $(\mathrm{OM}>10 \%)$, which is in line with the work of Hamssa (2018). The sedimentary layer of this lake is mainly sandy, with a maximum proportion of fine matter of $16.45 \%$. The average value of mercury in the sediment is $35.18 \mu \mathrm{g} / \mathrm{kg}$. This value is higher than that found in Lake Kossou (0.02 mg / kg) (Soussou, 2019). However, it remains lower than the average values obtained by Chouti (2010) in the Porto-Novo lagoon, which vary from $0.90 \mathrm{mg} / \mathrm{kg}$ to $2.73 \mathrm{mg} / \mathrm{kg}$ or even that found in the Ebrié lagoon $(0,50 \mathrm{mg} / \mathrm{kg}$ ) (Touré et al., 2018). Lake Nokoué is also shallow with a maximum depth of $3.46 \mathrm{~m}$ at its center.

\section{Correlation matrix}

The correlation tests between the various overall parameters (Table 2) reveal a high significance between the mercury content and the proportion of organic matter. The increase in the mercury concentration in the sediments is explained at $96 \%$ by the proportion of organic matter in the environment. In addition, organic matter is positively correlated with the fine fraction and negatively with the water $\mathrm{pH}$. This would reflect a dependence between the mercury content and the fine fraction which is not statically highlighted here. In fact, the finer the particle size of the sediment, the greater its capacity to accumulate trace metals present in the medium (Wedepohl, 1995).

Table 1: Statistical data of the parameters measured in the sediment.

\begin{tabular}{llllllll}
\hline Parameters & n & mean & median & min & Max & sd & se \\
\hline Organic matter (\%) & 135 & 16,62 & 14,73 & 1,29 & 46,16 & 12,90 & 1,11 \\
pH-water & 135 & 6,63 & 7,25 & 3,37 & 8,12 & 1,34 & 0,11 \\
eH & 135 & 29,69 & $-9,20$ & $-61,90$ & 216,20 & 79,82 & 6,87 \\
Fine fraction (\%) & 135 & 3,61 & 2,76 & 0,13 & 16,45 & 2,93 & 0,25 \\
Depth $(\mathbf{c m})$ & 135 & 118,96 & 115,00 & 8,00 & 346,00 & 65,55 & 5,64 \\
{$[\mathbf{H g}](\boldsymbol{\mu g} / \mathbf{k g})$} & 135 & 35,18 & 28,04 & 1,56 & 164,88 & 24,57 & 2,11 \\
\hline
\end{tabular}


Table 2: Correlation between the different parameters.

\begin{tabular}{lllllll}
\hline & MO & pH-water & eH & Fine- frac & Deep & Hg \\
\hline MO & 1,00 & $-0,41^{*}$ & $0,40^{*}$ & $0,46^{*}$ & $-0,31$ & $0,47^{*}$ \\
pH-water & & 1,00 & $-1,00$ & $-0,62$ & 0,40 & $-0,12$ \\
eH & & 1,00 & 0,62 & $-0,45$ & 0,11 \\
Fine fraction & & & & 1,00 & $-0,40$ & 0,11 \\
Depth & & & & & 1,00 & 0,19 \\
Hg & & & & & & 1,00 \\
\hline
\end{tabular}

* Significant correlation at the 0.04 level

\section{DISCUSION}

Each point of the lake presents a particularity in terms of the behavior of the various parameters (Figure 4). There is no significant difference regarding the variation in the percentage of organic matter whatever the zone considered on the lake. The north-west of the lake is different from all the other points by its $\mathrm{pH}$ values which are mainly $(50 \%)$ between 4 and $6 ; 25 \%$ of the samples have $\mathrm{pH}$ values below 4 .

A clear variability is observed in the proportion of the fine fraction $(<63 \mu \mathrm{m})$ at different locations of the lake. $50 \%$ of the samples in the North-West zone are made up of 5 to $15 \%$ of fine matter, versus $50 \%$ made up of 2.5 to $5 \%$. In the south-eastern part of the lake, the fine fraction varies very little ( 0 to $5 \%$ ) and is better distributed over the entire surface area considered.

There is a gradual variability with regard to mercury going from the northern zones to the southern zones. The northeast of the lake has low variability in the mercury content in the sediment compared to other lake environments. $50 \%$ of the samples in this part of the lake have mercury content that varies from 15 to $25 \mu \mathrm{g} / \mathrm{kg}$. This can be explained by the fact that the North East is under the influence of two large tributaries, the Ouémé river and the Porto-Novo lagoon. The water current would carry most of the surface sediments towards the south-eastern zone where a fraction would probably settle and the rest, under a much more moderate current due to the absence of an affluent, would reach the Cotonou channel. It emerges from all the above that in the southern zone of the lake, the finer the sediment, the higher the proportion of organic matter and the higher the mercury content, which confirms the correlation tests between the parameters studied.

In terms of classification of the zones according to a summation of their mercury concentrations (Figure 5), the South-East zone comes first, followed by the South-West zone, then the North-West zone and finally the North-East zone with concentration values respectively of: $530.3 \mu \mathrm{g} / \mathrm{kg}, 432.8 \mu \mathrm{g} / \mathrm{kg}$, $385.2 \mu \mathrm{g} / \mathrm{kg}$ and $259.5 \mu \mathrm{g} / \mathrm{kg}$ of sediment. In addition, the analysis of variances (Table 3 ) reveals a highly significant difference $(\mathrm{p}<$ 0.001 ) between the sampled points of the lake, the organic matter and the depth. Moreover, the mercury contamination of the lake is drained downstream, to be evacuated into the Cotonou channel, where it reaches an average value of $150.32 \mu \mathrm{g} / \mathrm{kg}$ (NP43 site).

The geo-accumulation index determination (Figure 6) according to the classification of Müller (1981) and Ruiz (2001) indicates that the overall mercury content of the lake at the considered sites is linked to the concentration of the metal background (Igeo < $0)$. Thus, Lake Nokoué does not present any mercury contamination. This is in agreement with the level of contamination of Lake Kossou (Soussou, 2019). On the other hand, the exit of the lake, which is the entry to the Cotonou channel, is found in the category of unpolluted 
to slightly polluted sediments $(0 \leq$ Igeo $\leq 1)$. Thus, the pollution of the lake sediments accumulates at the lake outlet to be evacuated into the marine environment through the Cotonou channel.

Moreover, by obscuring the effect of background noise, the calculation of the contamination factors (Figure 7) shows that the lake at its considered sites is moderately contaminated with mercury. Indeed, the values of FC values vary from 1 to 3 according to the classification of Rubio (2000). This contamination would therefore be linked to human activities.
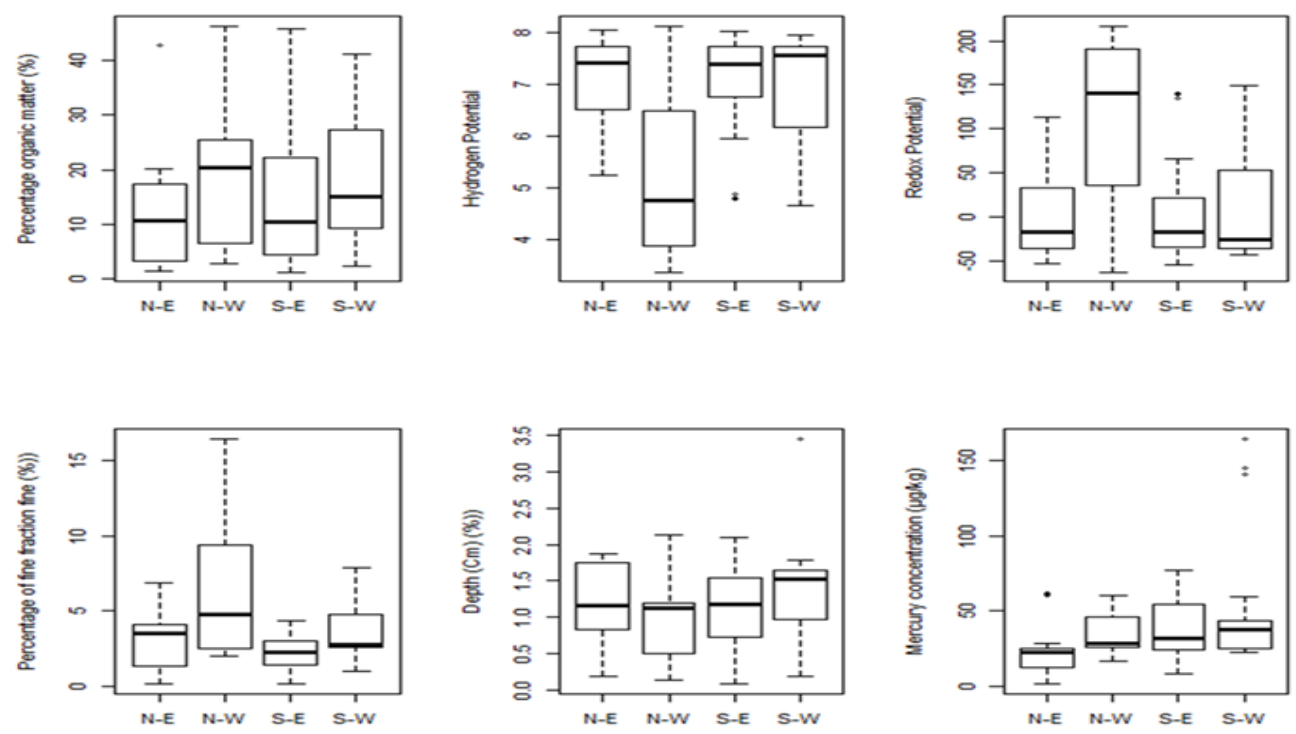

Figure 4: Distribution of the parameters studied according to the different zones of Lake Nokoué.

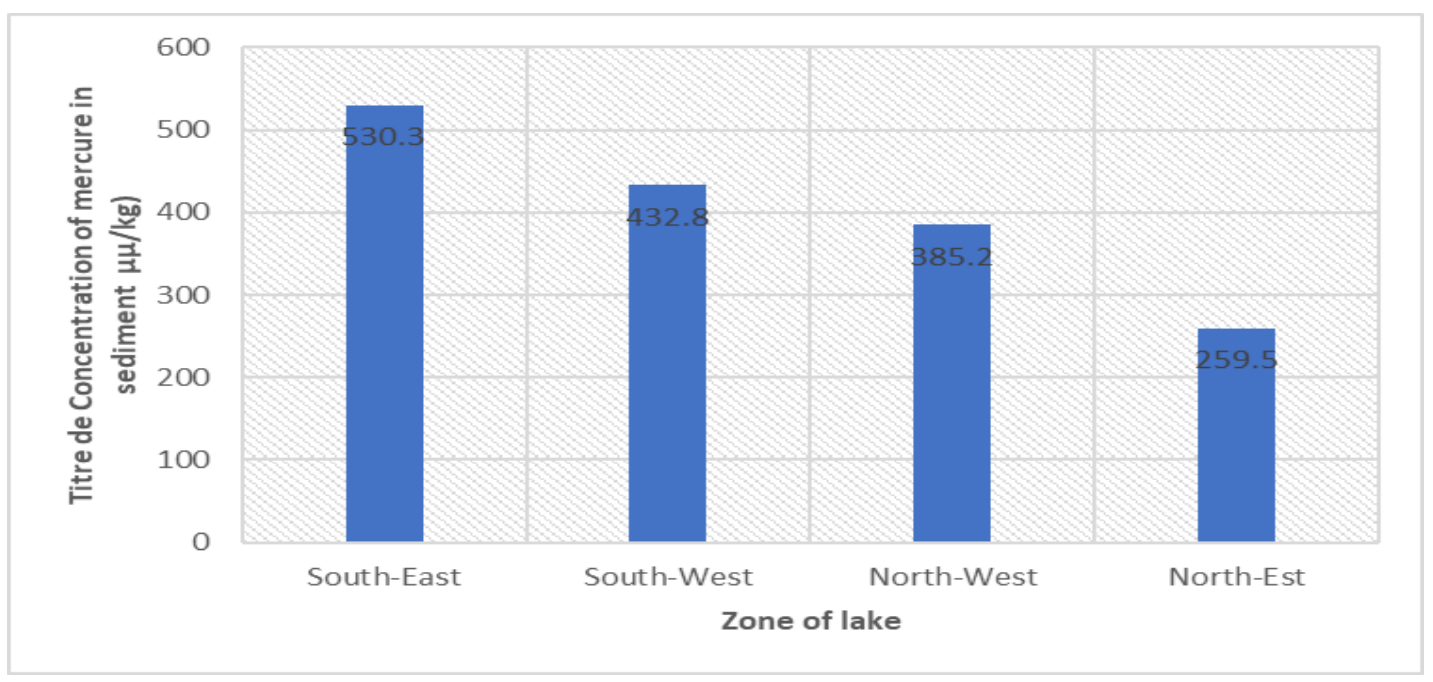

Figure 5: Classification of zones according to their mercury concentration. 
Table 3: Analysis of the variances of the studied parameters.

\begin{tabular}{lllllll}
\hline & Df & Sum & Mean & F value & Pr $(>\mathbf{F})$ & \\
\hline Zone & 3 & 12036 & 4012 & 10.755 & $2.42 \mathrm{e}-06$ & $* * *$ \\
eH & 1 & 1203 & 1203 & 3.225 & 0.0749 & \\
Fine fraction & 1 & 352 & 352 & 0.944 & 0.0749 & \\
pH & 1 & 205 & 205 & 0.550 & 0.4597 & \\
OM & 1 & 12662 & 12662 & 33.944 & $4.46 \mathrm{e}-08$ & $* * *$ \\
Depth & 1 & 7438 & 7438 & 19.939 & $1.76 \mathrm{e}-05$ & $* * *$ \\
\hline
\end{tabular}

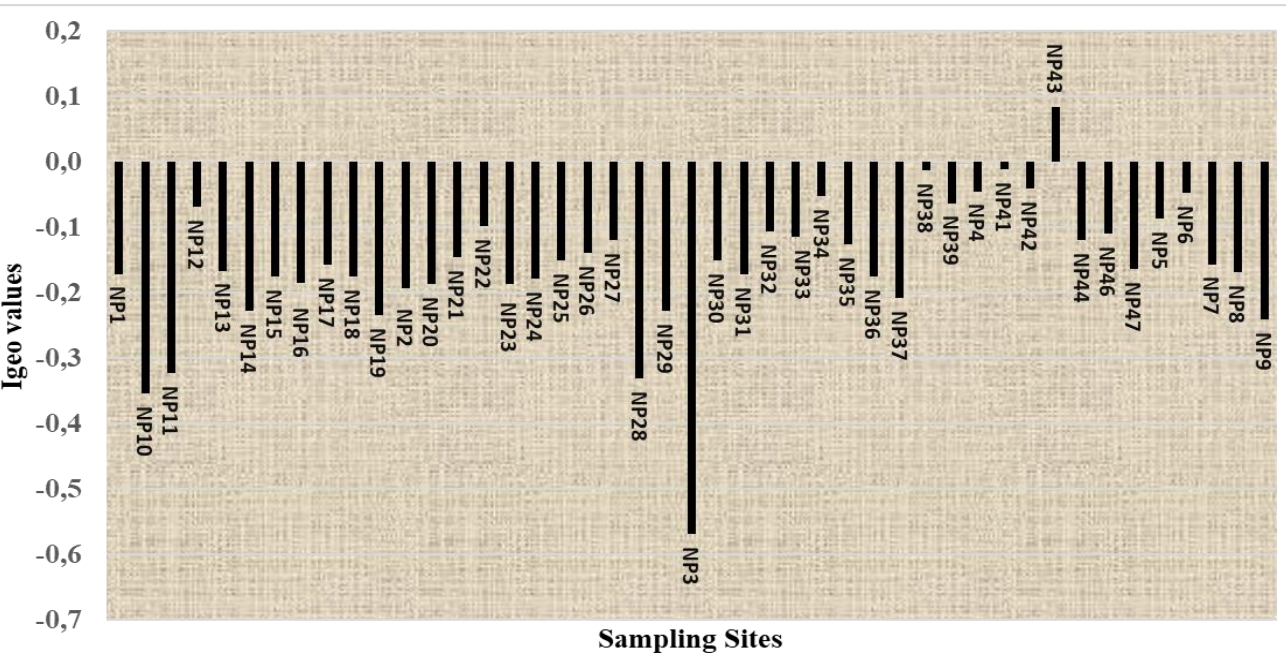

Figure 6: Representation of geo-accumulation index by sampling site.

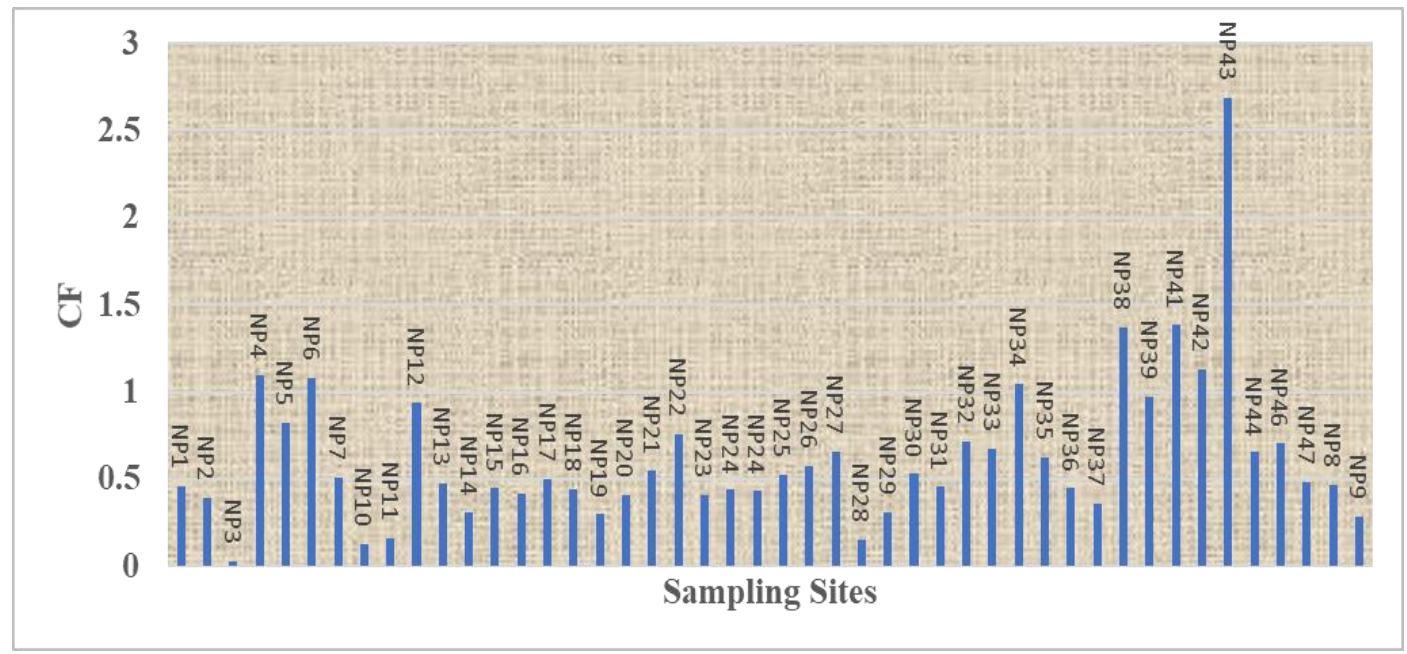

Figure 7: Representation of growth factors by sampling site. 


\section{Conclusion}

The concentration of mercury in the sediments varies from one point to the other of the lake depending on the area and the proportion of organic matter. Areas that are influenced by human activities, including lakeside towns and wild dumpsters, have the highest mercury levels. The very good distribution of the sediment in the south-east of the lake, which receives the sediment flows coming from the upstream of the north lake, has a high concentration of mercury which correlates with the proportion of organic matter in the sediment. In addition, the finer the sediment, the higher the organic matter and the higher the mercury content. The moderate mercury contamination observed in this aera of study requires regular monitoring in order to anticipate extreme mercury pollution that may be linked to anthropogenic pressures to which Lake Nokoué is subject.

\section{COMPETING INTERESTS}

The authors of this articles declare that they have no competing interest.

\section{AUTHORS' CONTRIBUTIONS}

NBNA as the first author wrote this article with contributions from the other authors. PH contributed to the realization of the work through the funding of the sampling campaigns, and part of the literature review. JGA supervised the work and did quality assurance for the document. HWD improved the article by proofreading the document. MPA contributed to the improvement of the article by providing advice and ensuring the quality of this manuscript.

\section{ACKNOWLEGEMENTS}

The authors thank the coordinator of LESE for giving free access to the laboratory facilities for various analyzes.

\section{REFERENCES}

Adechina RAMA, Kelome NC, Kaki C, Hounkpe JB, Randriana NRF. 2019.
Evaluation of contamination risks in Metallic Trace Elements (MTE) in the sediments of Ouémé delta in Benin.: International Journal of Innovation and Applied Studies, 27(4): 943-954.

Agonkpahoun E. 2006. Assessment of the pollution of continental waters by toxic metals: Case of the Okpara river and of the Nokoué lake in Benin. Benin: PhD Thesis in Pharmacy, University of Abomey-Calavi, Abomey-Calavi, Benin, p. 87.

Alassane Y, Abdou K, Mahamadou D, Abdoul K Al, Daouda M, Issaka Y and Abdou K. 2018. Sources and Distribution of Mercury Residues in Environmental and Food Matrices of the Mekrou River Watershed in Kèrou, Kouandé and Péhunco in Republic of Benin. American Journal of Applied Chemistry, 6(2): 5763. DOI: 10.11648/j.ajac.20180602.14.

Chouti W, Mama D, Changotade O, Alapini F, Boukari M. 2010. Study of metallic trace elements contained in the sediments of the Porto-Novo lagoon (South Benin). Journal of Applied Biosciences, 34: 21862197.

Chouti W, Mama D, Alassane A, Changotade O, Alapini F, Boukari M, Aminou T, Afouda A. 2011. Physicochemical characterization of the Porto-Novo lagoon (south Benin) and highlighting of pollution by mercury, copper and zinc. Journal of Applied Biosciences, 43: 28822890.

Degila HW, Azon NBN, Adounkpe JG, Akowanou AVO, Aïna M P. 2019. Mercury: sources of emission, toxicity, contamination of the aquatic environment and particularity of Benin. Int. J. Biol. Chem. Sci., 13(7): 3429-3448. DOI: https://dx.doi.org/10.4314/ijbcs.v13i7.36

Darboux E. 2008. Contribution to the evaluation of the relationship between anthropogenic activities, the pollution of Lake Nokoué and the general state of health of the neighboring populations: 
Case of the Ladji-Ahouansori-Ganvié and Sotchanhoué zones. End of training report, University of Abomey-Calavi, Abomey-Calavi, p. 92.

Diop C. 2014. Study of contamination, speciation and bioavailability of metallic trace elements in coastal and estuarine waters and sediments in Senegal: Assessment of potential toxicity. $\mathrm{PhD}$ thesis University of Lille, France, p.199.

Dominique Y. 2014. Contamination by different chemical forms of mercury of the component of the Petit-Saut hydroelectric dam and of the upstream / downstream areas of the Sinnamary river, in French Guiana (in situ study and experimental approaches. Senegal). PhD thesis, University of Geneva, Geneva, p.121.

Dovonou F, Aïna MP, Boukari M, Alassane A. 2011. Physico-chemical and bacteriological pollution of an aquatic ecosystem and its eco-toxicological risks: case of Lake Nokoue in South Benin. Int. J. Biol. Chem. Sci., 5(4): 1590-1602. DOI:

http://dx.doi.org/10.4314/ijbcs.v5i4.23.

Hamssa D, Saliha KN, Dounia K, FatimaZohra AM. 2018. Content of Metallic Trace Elements $\mathrm{Cu}, \mathrm{Zn}$ and $\mathrm{Pb}$ of the Sediments of the Blessed Haroun Dam (North-East of Algeria). European Scientific Journal, 14(15): 269-286. DOI: 10.19044/esj.2018.v14n15p269

Hounkpatin ASY, Edorh AP, Salifou S, Gnandi K, Koumolou L, Agbandji L, Aissi K. Alain, Gouissi M, Boko M. 2012. Assessment of exposure risk to lead and cadmium via fish consumption in the lacusrian village of Ganvié in Benin republic. Journal of Environmental Chemistry and Ecotoxicology, 4 (1): 1-10. DOI: 10.5897/JECE11.063.

Hounkpe JB, Kelome NC, Lawani RAN, Adechina A. 2017. Inventory of pollution of aquatic ecosystems in benin (West Africa). Larhyss Journal, 30: 149-171.
Keumean KN, Bamba SB, Soro G, Soro NM, Soro B, Biemi J. 2013. Concentration of heavy metals in the sediments of the Comoé river estuary at Grand-Bassam (South-East of Côte d'Ivoire). Journal of Applied Biosciences, 61: 4530-4539. DOI: 10.4314/jab. v61i0.85599

Macdonald DD, Ingersoll CG, Berger TA. 2000. Development and evaluation of consensus-based sediment quality guidelines for freshwater ecosystems. Arch. About. Con. Tox., 39: 20-31. DOI: 10.1007/s002440010075

Müller G. 1981. Heavy metal pollution of the Neckars sediments and its tributary: an inventory. Chemical Zeitung., 105: 157164.

Nahli A, Hebabaze S, Iounes N, Abderrahmane B, Chlaida M. 2016. Study of metallic contamination of surface sediments of Oued Hassara after installation of the treatment plant (StEp) of Médiouna (Casablanca, Morocco). Rabat: Bulletin of the Scientific Institute, Life Sciences Section; 38: 1-14.

Lawani L. 2007. Study of the pollution of water, sediments and shrimps of Lake Nokoué by metals $(\mathrm{Pb}, \mathrm{Cd}, \mathrm{Cu}, \mathrm{Zn}, \mathrm{Fe})$ in Benin. End-of-training dissertation for obtaining a graduate degree specializing in planning and resource management. End of training report. University of Abomey-Calavi, Abomey-Calavi, p.94.

Rubio B, Nombela MA, Vilas F. 2000. Geochemistry of major and trace elements in sediments of the Ría de Vigo (NW Spain): An assessment of metal pollution. Marine Pollution Bulletin, 40: 968-980. DOI: $10.1016 / \mathrm{s} 0025-$ 326x(00)00039-4.

Ruiz F. 2001. Trace metals in estuarine sediments from the southwestern Spanish Coast. Marine Pollution Bulletin, 42 : 482-490. DOI: $10.1016 / \mathrm{s} 0025-$ 326x(00)00192-2.

Saher NU, Siddiqui AS. 2016. Comparison of heavy metal contamination during the last 
decade along the coastal sediment of Pakistan : multiple pollution indice approach. Mar. Pollut. Bull, 105: 403410.

DOI:

10.1016/j.marpolbul.2016.02.012.

Sahli L. 2012. Study of the behavior of some flora and fauna species in aquatic life with respect to metallic trace elements by bioassays. $\mathrm{PhD}$ thesis, Mentouri University of Constantine, Algérie, p.262.

Soussou YI, Akesse DPV, Kouame KV, Yapi DAC, Yapo OB. 2019. Assessment of trace metal contamination of sediments in Lake Kossou (Côte d'Tvoire). J. Chem. Organic. Phy. Sci. Sec., 9(3): 217-229. DOI: 10.24214/jcbps.D.9.3.21729.

Toure M, N'Guessan AY, Konan EK. 2018. Geochemical study of the surface sediments of a lagoon bay and its impact on the environment: Case of Abouabou bay (Ebrié lagoon; Ivory Coast). Int. J. Biol. Chem. Sci., 12 (5): 2371-2380. DOI: https://dx.doi.org/10.4314/ijbcs.v12i5.35
Wedepohl KH. 1995. The composition of the continental crust. Geochimica and Cosmochimica Acta, 59(7): 1217-1232. http://dx.doi.org/10.1016/00167037(95)00038-2.

Yehouenou EAP, Adamou R, Azehoun PJ., Edorh PA, Ahoyo T. 2013. Monitoring of Heavy Metals in the complex "Nokoué lake - Cotonou and Porto-Novo lagoon" ecosystem during three years in the Republic of Benin. Research Journal of Chemical Sciences, 3(5): 12-18.

Youssao A, Soclo HH, Bonou C, Vianou K, Gbaguidi M, Dovonou L. 2011. Assessment of the contamination of ichthyan fauna in the complex Nokoué lagoon - Cotonou channel by the lead: case of Sarotherodon melanotheron, Tilapia guineensis and Hemichromis fasciatus species (Benin). Int. J. Biol. Chem. Sci., 5(2): 595-602. DOI: 10.4314/ijbcs.v5i2.72125 